\title{
CONCEPTIONS OF JAPAN'S SECURITY AFFECTING COOPERATION WITH THE UNITED NATIONS
}

\author{
Wakamizu Tsutsui*
}

This article analyses the vexed question of the interaction of Japan's post-War Constitution, the San Francisco Peace Treaty, and the Japan-US Security Treaty. It compares the initial conceptions of Japanese security in relation to the United Nations with conceptions engendered by the Korean War and more recent peace-keeping operations. It concludes with some implications for Japan's security in a post-Cold War era.

\section{THE DEBATE ON JAPAN'S SECURITY AFTER CONCLUDING PEACE \\ A "Renunciation of War" under the Peace Constitution}

The Instrument of Surrender signed on 2 September 1945 by Japan directed Japan to cease hostilities with the Allied nations, and commanded all civil, military and naval officials to obey and enforce all orders of the Allied Powers giving effect to the Instrument. The Instrument was made pursuant to the Potsdam Declaration of 26 July 1945, which proclaimed the terms for Japanese surrender. The terms included the renunciation of Japanese interests overseas and destruction of her power to wage war. In implementing these terms, Japanese territories were occupied by the Allied Forces, most of which were from the United States of America. In this regard, paragraph 12 of the Potsdam Declaration stated: "The occupying forces of the Allies shall be withdrawn from Japan as soon as these objectives have been accomplished and there has been established in accordance with the freely expressed will of the Japanese people a peacefully inclined and responsible government."

The Constitution of Japan was drafted in February 1946 by the staff of the occupation authority under the direction of the United States Army General and Supreme Commander of the Allied Powers, Douglas MacArthur. The Draft was shown to the Japanese Government and published as the Draft Constitution of the Japanese Government. The present-day

* Professor of International Law, Law Faculty, Hitotsubashi University, Tokyo. 
Constitution of Japan, promulgated on 3 November 1947, originates in the draft of occupation forces staff. ${ }^{1}$

Japan's "Peace Constitution" is exceptional in including a "Renunciation of War" clause, article 9, originating in the second of "the three basic points" given by General MacArthur to his staff as indispensable for constitutional revision. It is patterned after the Renunciation of War Pact of 1928, and a part of article 2 paragraph 4 of the United Nations Charter. However, article 9 of the Constitution goes so far as to stipulate that: "land, sea and air forces as well as other war potential will never be maintained. The right of belligerency of the state will not be recognised."

In fact, this did not bring about anything new, because such was Japan's situation at that time. However, the occupation would eventually end, upon the conclusion of the Peace Treaty between Japan and the Allied nations. If the Constitution remained valid after peace was formally concluded, the power vacuum engendered by the withdrawal of the existing occupation forces would be left unfilled. The desirability of the earliest possible conclusion of a Peace Treaty was evident; the US authorities felt "that he [General MacArthur] is a hundred percent right as to an early Japanese treaty." 2 Thus, the question was how Japanese security could be assured after peace, as long as the Constitution continued to be valid.

\section{B The Security of Japan Trusting in "Peace-Loving Peoples"}

A phrase in the Preamble of the Constitution may be a key to the solution on the security after withdrawal of the occupation forces: "We have determined to preserve our security and existence, trusting in the justice and faith of the peace-loving peoples of the world." Under article 4 of the Charter, membership of the United Nations is conditional on being "peace-loving". Thus, it might be construed that the United Nations would provide the actual mechanism to ensure Japanese independence under conditions of renouncing land, sea and air forces.

Security trusting in the United Nations was also the solution envisaged by General MacArthur. The second of "the three basic points" stated that "it [Japan] relies upon the higher ideals which are now stirring the world for its defence and its protection".

1 K Takayanagi, I Ohtomo and H Tanaka Nikonkoku Kenpo Seitei no Katei [The Making of the Constitution of Japan] Volume 2 (Yuhikaku, Tokyo, 1972).

2 Foreign Relations of the United States, Volume 6: The Far East (Department of State, Washington DC, 1947) 461. 
Furthermore, in his memorandum on the means of the security to be stipulated in the peace treaty, he stated: ${ }^{3}$

It is therefore incumbent that the Allied Nations for their part, in the spirit of this constitutional provision, undertake to guarantee the neutrality of Japan, with the view to the transfer of such undertaking to the stewardship of the United Nations, where the responsibility properly should rest.

According to MacArthur, the Constitution "has taken an advanced position in the evolution of civilisation through its renunciation of war, of the future maintenance of armed force, and of all sovereign rights of belligerency." ${ }^{4}$ Independence under the stewardship of the United Nations was inseparable from political reforms carried out under the Allied occupation. Since a peace treaty should provide for "the complete withdrawal of direct military controls", Japanese people had to be given the right to appeal to the United Nations on "the deprivation of any fundamental right or the emasculation of any basic reform granted or instituted during the period of occupation". 5

This view did not accord with the Draft of the US State Department that a disarmed Japan, with certain exceptions such as minimum defence forces and with a permanent neutrality policy, would be placed under the guard of the four main neighbouring states: the United States, the United Kingdom, the Soviet Union, and China. ${ }^{6}$ MacArthur's memorandum was a counter-argument to Washington's response to his view on how to conclude peace with Japan, expressed in a press interview in Tokyo on 17 March 1947.?

To the people and the government of Japan, the most important thing was how to negotiate an early peace treaty. Considering the Constitution in the Diet, Prime Minister Shigeru Yoshida expressed the following view: ${ }^{8}$

The renunciation of war clause in the Constitution might imply no use of the right of selfdefence, on condition of access to United Nations membership. I am not concerned with that. What is urgent for us is the recovery of sovereignty and independence as early as possible. This is the question that our government has been most concerned about. We are

3 Above n 2, 456.

4 Above n 2, 456.

5 Above n 2, 452.

6 Reported in Japanese newspapers, eg Asahi Shimbun, 23 June 1946. According to the reports, the draft was circulated to the relevant states, who responded mostly favourably.

7 Above n 2, 452.

8 Upper House, 27 August 1946: W Tsutsui, et al, Nihonkoku Kemposhi [A History of the Constitution of Japan] (University of Tokyo Press, Tokyo, 1976) 424. 
endeavouring to have the earliest chance of concluding a peace treaty with the Allied nations. On your question concerning the renunciation of war and the right of self-defence, what I just said was the right answer.

Japanese people and the Government were not in a position to know whether the General's policy had been developed after full consultation with the United States government in Washington or not. If Japan thought how to achieve security after independence, she only had the views of the Allied nations made known through the statements of General MacArthur and his staff.

What was certain was that acceptance of the Constitution was the prerequisite to peace with the Allied nations. Nevertheless, negotiations for a peace treaty did not immediately follow the adoption of the Peace Constitution. While peace with the Axis powers except Germany and Japan had been completed by 1947, peace with the latter two nations was too serious a matter to be forced through in disregard of the growing split within the Allied nations. When the anxiety about the delay in concluding peace on the part of the Japanese government and people was at its peak, the Korean War broke out, on 25 June 1950. This war broke the deadlock concluding peace, but in an exceptional way.

The Peace Treaty between Japan and the Allied nations was eventually concluded at San Francisco on 8 September 1951. It was incomplete in the sense that the Allied parties were limited to those belonging to the West. The other states including the Soviet Union and the People's Republic of China, the revolutionary regime in mainland China, were excluded. This was a natural consequence of the opposition between the two groups reaching its climax, driving one group to the instant peace with their former enemy.

Under these circumstances, the Peace Treaty concluded could not entail the withdrawal of United States forces from Japanese territory. To resolve the inconsistency of continued stationing of US forces and the making of peace, the Treaty of Mutual Cooperation and Security between Japan and the United States of America (the Japan-US Security Treaty) came into effect simultaneously with the Peace Treaty.

The question of how the security of Japan was to be secured after evacuation of the Allied occupation forces, as a result of making peace, was postponed. On the other hand, a new question arose as to whether continued occupation contravened the Japanese Constitution, which was still valid after peace. Either the Treaty or the Constitution might be proved irrelevant, in the light of the initial conception of Japan's security after peace, demonstrated by the Allied authorities and accepted as a matter of course by the Japanese people and their government. 


\section{The Japan-US Security Treaty: A Dubious Solution}

The Japan-US Security Treaty permitted the garrisoning of US forces in Japan, for them to contribute to the security of Japan as well as to maintain peace and security in the Far East. ${ }^{9}$ This was the mechanism for filling the power vacuum created by the Peace Treaty. On the other hand, it was open to doubt in the light of essence of the Peace Treaty, which was to remove every effect of war and the ensuing occupation. ${ }^{10}$ There was also the observation of General MacArthur, made eleven weeks before the outbreak of the Korean War, that $95 \%$ of the Japanese people were opposed to American bases in Japan. ${ }^{11}$ However, it was undeniable that the outbreak of Korean hostilities had radically changed the situation envisaged in the Potsdam Proclamation and the post-surrender policy of the US.

To deal with the new situation, the possibility of establishing Japanese contingents under article 43 of the United Nations Charter was suggested by a US authority. ${ }^{12}$ Had this been carried out, Japanese forces would not have been placed at the disposal of the Security Council assisted by the Military Staff Committee, consisting of the Chiefs of Staff of the permanent members in employment and command of forces. ${ }^{13}$ Japanese forces to be established according to the Charter would have been placed at the command of the General of the United Nations Forces in Korea - the General of the occupation army, Douglas MacArthur.

Meanwhile, Shigeru Yoshida contributed an article to an American journal stating that the experiences in Korea provided a path to future Japanese security. He was appreciative of the actions of the United Nations in Korea, writing: ${ }^{14}$

We know now that defenceless Japan will not be left undefended in her hour of need. It is with an abiding faith in the solidarity of free nations that we shall look to the United Nations for protection of our liberty and independence. I hope that the eventual peace treaty will

9 Treaty article 6.

10 This was not the situation that Prime Minister Shigeru Yoshida foresaw in the course of promoting a peace treaty. It might be the reason why he did not join others in signing the Treaty on behalf of Japan.

11 Memorandum of Conversation on American bases in Japan between General MacArthur and $\mathrm{Mr}$ Sebald, 6 April 1950: Foreign Relations of the United States, Volume 6 (Department of State, Washington DC, 1950) 1170-1171.

12 This was suggested by Mr Dulles, according to an unsigned memorandum by the Policy Planning Staff in Washington, 26 July 1950: above n 11, 1256-1257.

13 Charter articles 43, 46, 47.

14 Shigeru Yoshida "Japan and the Crisis in Asia" (1951) 29 Foreign Affairs 171. 
provide for Allied support of Japan's entry into the United Nations, so that we may participate in its efforts to establish conditions of security in the Far East.

As mentioned, at an early stage of the concept - when the Peace Constitution was enacted - security by the United Nations assumed the withdrawal of the occupation forces, with Japan being disarmed under the Peace Constitution. However, at the outbreak of Korean hostilities, the US forces stationed in Korea responded to the offensive in cooperation with the South Korean army. They were "United Nations Forces" in the sense that they were based on the decisions of the Security Council taken after the report of the incident in Korea. Security by the United Nations then assumed that foreign forces would act in the name of the United Nations if an incident occurred as in Korea. Yoshida's article shows that he had accepted this change in the substance of the United Nations, in the face of the outbreak of hostilities off the Japanese mainland. Nevertheless, those who adhered to the initial concept of security by the United Nations did not accept the change. According to them, the United Nations actions in Korea were not in accordance with Charter principles, in pushing matters to the brink of a third World War. Their beliefs were confirmed by the "failure" of the United Nations actions to defeat the "aggressors".

The United Nations actions in Korea were based on decisions as to "breaches of the peace", although they did not cite the specific provisions of article 39 of the Charter. The member states were recommended to cooperate with activities in assisting South Korea. In this context, they were the doubtless "United Nations Forces", directed by the General of the United Nations forces in Korea, who was appointed by the US President according to the resolution of the Security Council. However, given the initial conceptions on security, the practices of the United Nations Forces in Korea did not clear away doubts as to the USJapan Security Treaty of 1951, concluded as "a provisional arrangement for Japanese defence." 15 It was security not by United Nations Forces, but by US Forces in action in the capacity of United Nations Forces in Korea. This was one reason for the opposition to the San Francisco Peace Treaty in Japan - the other important reason being that it failed in securing "total peace" for Japan.

\section{THE UNITED NATIONS: INTEGRAL TO JAPAN'S SECURITY}

\section{A The United Nations to be Neutral in Action}

To maintain international peace and security during the Cold War, the United Nations developed "peace-keeping" activities. According to the recent Report of the SecretaryGeneral entitled An Agenda for Peace, peace-keeping is the deployment of a United Nations

15 US Draft, 31 July 1951: Foreign Relations of the United States, Volume 6 (Department of State, Washington DC, 1951) 1233. 
presence involving military personnel with the consent of all the parties concerned. ${ }^{16}$ According to an earlier United Nations publication, this originates in UNTSO, sent to the Middle East in 1948. ${ }^{17}$ There were similar practices under the League of Nations, such as the electoral supervision in the Saar Territory in $1935 .{ }^{18}$ The United Nations activities involving the Greek border and the independence of Indonesia were of the same sort, although they are not listed in these publications as examples of "peace-keeping". Although the Report of the Secretary-General states that peace-keeping can rightly be called the invention of the United Nations, ${ }^{19}$ it is not the invention of the United Nations but rather a normal function of international bodies or personnel.

Peace-keeping became conspicuous during the polarisation of the Security Council, when the United Nations was inactive in carrying out its primary purposes. Accordingly, it might be right to say that such operations were characteristic of the Cold War period. Nevertheless, the fact is that such operations have increased in number since the end of the Cold War. This is because of recent redefinition of peace-keeping so as to encompass civilian activities. As a result, it has come to include supervision of elections, advice on administrative affairs, distribution of food and clothing, and so on. On the other hand, the requirement of consent of all parties concerned has come to be relaxed in some cases, as when Iraq was not consulted in sending UNIKOM to Iraq and Kuwait in 1991.

In any event, "peace-keeping" activities are distinct from enforcement actions in their restricted and neutral nature. The United Nations is exceptional in putting claws into the system through enforcement measures, which were foreign to the League of Nations system. If Japan could be guarded only through neutral and impartial institutions, the United Nations would not be qualified to be a guardian engaging in its most prominent operations.

However, the United Nations acting impartially is consistent with the ideology of the Peace Constitution. In the 1950s, a Japanese writer argued that the United Nations Police Force should replace US Forces garrisons. ${ }^{20}$ This was motivated by the success of the peace-keeping operations of UNEF in the Suez in 1956. This resembled an earlier argument

16 (A/47/277-S/24111, United Nations, New York, 17 June 1992) para 20.

17 The United Nations The Blue Helmet: A Review of UN Peace-Keeping (United Nations Department of Public Information, New York, 2 ed, 1990).

18 F P Walters A History of the League of Nations (Oxford University Press, Oxford, 1952) 586.

19 Above n 15, 46.

20 Yoshikazu Sakamoto "Churitsu Nikon no Boei Koso - Nichibei Ampokoso ni Kawarumono [A Defence Plan for Neutral Japan - An Alternative to the Japan-US Security System]" (1958-9) Sekai 31. 
for "permanent neutrality" as the way to achieve Japanese security, ${ }^{21}$ and the declaration of 15 January 1950 by 35 intellectuals calling for a peace treaty with all the Allied nations.

This "neutrality formula" might have been possible for Japan in the late 1940s, but the peace with certain Allied nations in San Francisco was made under circumstances adverse to such a formula, requiring her to collaborate with the occupation forces in the name of United Nations cooperation. In this context, neutrality could be perceived as the antithesis of the actual solution, taken by the government in opposition to the Japanese people.

\section{B The Law on Peace Cooperation}

Operations in the Middle East by the "multi-national forces" in 1991 was an indication that the actions in the name of the United Nations had gone beyond those of peace-keeping, which was conspicuous in the Cold War period. Japan could not be indifferent to the operations, because the multi-national forces were led by the US, the bases of whose forces were situated in Japanese territory.

To deal with the situation, the Japanese government moved to enact a law to facilitate cooperation with any activities taken to implement the decisions of the United Nations. Unavoidably, such cooperation depends on Japanese "Defence Force" personnel. The first draft of 1990 was withdrawn, after deliberations in the Diet, with many ambiguities left undiscussed. A renewed draft was brought up for discussion. This set out five conditions to be satisfied in participating in "international peace operations":

(1) Cease-fire agreement among conflicting parties to the armed conflict;

(2) Consent by such parties on United Nations peace-keeping activities being undertaken, and also on Japan's participation in them;

(3) Impartiality of the United Nations activities;

(4) Withdrawal of Japanese contingents and personnel when the above requirements cease to be satisfied; and

(5) Limitation of the use of weapons, to the extent deemed reasonable and necessary for self-protection.

On the basis of these conditions, the Law Concerning Cooperation for United Nations Peace-keeping Operations and Other Operations (or the "International Peace Cooperation Law") was passed in the Diet in $1992 .{ }^{22}$

21 Yasuo Yamashita, "Eisei Churitsu ni tsuite [On Permanent Neutrality]" (1950-4) Chuokoron 18.

22 Law No 79, 19 June 1992. 
The Law departs from the first draft in that it restricts cooperation strictly to that satisfying the requirements of the "Five Principles" listed above. Accordingly, cooperation under the Law is restricted to "peace-keeping" defined in terms of "the consent of the parties, impartiality and non-use of force except in self-defence", according to a subsequent Report of the Secretary-General. ${ }^{23}$

However, peace-keeping has been neither consolidated nor conclusive, as is pointed out in the United Nations publication mentioned above. ${ }^{24}$ Japanese authorities do not deny this, which was also the view of the party in government (the Liberal Democrats) and the other two parties in favour of the Law. ${ }^{25}$ In the view of the Japanese government, peacekeeping forces entrusted with peace-keeping actions are different from military forces. They need not engage in forcible actions, unlike ordinary military forces which enforce their aims. ${ }^{26}$ In practice, peace-keeping ranges from enforcing peace to observing elections, so there is "a grey zone" between admissible and inadmissible cooperation in the application of the International Peace Cooperation Law. Therefore, the three parties in favour of the legislation reached agreement to "freeze" certain categories of tasks involving cooperation under the Law.

The "frozen" tasks include almost all of the main activities of "International Peace Cooperation Assignments": monitoring and observance of cessation of armed conflicts; stationing and patrolling in buffer zones; collection of abandoned weapons; assistance in designating cease-fire lines; assistance in the exchange of prisoners-of-war. ${ }^{27}$ As a result, Japan's cooperation is limited to such tasks as electoral observation and supervision; advice on administrative affairs; medical assistance, transportation, communication and construction; assistance in repatriation; distribution of food, clothing, medical supplies and so on; rehabilitation of facilities and natural environment damaged by conflicts. ${ }^{28}$ Most of

23 Supplement to An Agenda for Peace (A/50/60-S/1995/1, United Nations, New York, 3 January 1995) para 33.

24 Above $n 17,8$.

25 A view presented by the Liberal-Democrats, Komeito and the Democratic Socialists to the House of Councillors, 4 June 1992, stating that the concept of peace-keeping is not strictly defined: Record of the Special Committee on the International Peace Cooperation Law (House of Councillors, Tokyo, 4 June 1992).

26 Statement of the Chief Cabinet Secretary, 19 September 1991: reported in the Asahi Shimbun that day, evening ed, 1-2).

27 International Peace Cooperation Law, article 3(3)(a)-(f); Annex, article 2.

28 International Peace Cooperation Law, article 3(3)(g)-(1). 
the possible cooperation is logistical. ${ }^{29}$ Furthermore, activities executed by civilians, such as assistance in elections, have not raised any problems regarding Japan's participation. Under the Law, Japanese participation in peace-keeping operations has come to include those in Angola, Cambodia, Mozambique, El Salvador, the Golan Heights, and Rwanda.

\section{JAPAN'S SECURITY UNDER THE NEW WORLD ORDER}

\section{A The United Nations from the Standpoint of the Peace Constitution}

Cooperation with the United Nations Forces was developed by the government, but was restricted by public opinion to cooperation influenced by the initial concept of security by the United Nations under the Peace Constitution. A number of points emerge from this tension.

First of all, United Nations cooperation under the International Peace Cooperation Law is consistent with that premised on "security by the United Nations" in its neutrality and impartiality. It is accepted as the ideal means of security for a state which has "renounced war" since the enactment of the Peace Constitution.

Secondly, however, it is an idealistic form of cooperation which pays little heed to the realities of international affairs involving Japan. Just as the withdrawal of US forces from Japan was unrealistic in 1950, cooperation restricted to peace-keeping will be inadequate under post-Cold War circumstances.

Thirdly, adherence to cooperation with the United Nations in a "neutral or impartial" manner drives the US-Japan Security Treaty to invalidation. Even if United Nations decisions give its members grounds to use their forces, Japan would reject cooperation with members having recourse to force. When the US forces stationed in Japan were mobilised pursuant to United Nations decisions, they could not be assisted by Japan as the territorial state because the Peace Constitution did not allow it.

A fourth point is more complicated. When the means to achieve security for Japan was considered during the Allied occupation, "security by the United Nations" would not have been accepted as involving assistance in enforcement actions. According to the understanding at that time, Japan could be permitted to discharge her obligations to the extent required by international agreements with the Allied nations. The Constitution was adopted on the assumption of a strict obligation of "renunciation of war" under such agreements. In spite of the Constitution originating in the will of the occupation authorities, provisions on disarmament were not to be found in the Peace Treaty at San Francisco. When Japan acceded to the United Nations in 1956, no reservation was made for

29 Secretariat of the International Peace Cooperation Headquarters Path to Peace: Japan's Contribution to World Peace (Jiji Gaho Sha, Tokyo, 1996). 
cooperation with enforcement actions. As a matter of fact, no member had been requested to assist in such actions, owing to the inaction of the Security Council.

However, the obligation to participate in forcible actions is highly probable, in as far as the Charter contains detailed stipulations on enforcement measures. From a theoretical standpoint, members of the United Nations cannot be exempt from discharging obligations to assist in enforcement actions, ${ }^{30}$ without forcible means. In contrast to enforcement actions, there are no express stipulations on peace-keeping in the Charter. Once the difficulties in applying the explicit stipulations on the Charter are removed, the "Multinational Forces" rather than Peace-Keeping Forces will become the appropriate United Nations Forces.

There is a strong possibility of mobilisation of US forces in Japanese bases in the event of Japan carrying out United Nations decisions made in accordance with Charter provisions. The first draft on Peace Cooperation was motivated by the need for cooperation with the multinational forces in 1991, an important portion of which were composed of US forces. If the Diet had passed the draft legislation, Japanese cooperation with the United Nations would have been more flexible because conditions would not have been restricted to peace-keeping. It might have given grounds for assistance in enforcement actions authorised for member states by the decisions of some United Nations organisations. Such flexibility in the draft legislation was the very reason why it was not passed by the Diet. This cannot be explained without understanding the effect of the initial conceptions regarding the security of Japan, premised on the Peace Constitution and guardianship by the United Nations as an "impartial" organisation of "peace-loving peoples". However, the initial situation has changed because of the continuing presence of US forces even after peace, and the repeated practice of United Nations decisions mobilising such forces.

\section{B Japan's Future Security}

In accordance with article 103 of the United Nations Charter, the Charter prevails over the obligations under any other agreements the member states conclude. This means that the US forces in Japan cannot be mobilised without grounds in the Charter. On the other hand, armed action of a state's own volition is possible subject to article 51 of the Charter, "individual or collective self-defence". An aim of the revision of the former Japan-US Security Treaty in 1960 was the affirmation of this pre-condition to mobilising US forces.

The revised Treaty left unresolved the problem of whether Japan acts in self-defence when the US mobilises forces in Japanese territory not for the defence of Japan, but for the purpose of maintaining peace and security in the Far East, in terms of article 6 of the Treaty. The Charter legalises Japanese action in cooperation with the US under article 6 for 
collective self-defence. Nevertheless, the Japanese government interprets the Constitution as prohibiting recourse to the right of collective self-defence.

On the other hand, there is neither express stipulation nor definite interpretation of the Constitution with respect to cooperation with actions authorised by the United Nations. In the light of article 103 of the Charter, cooperation with US forces in Japanese territory is not required beyond that provided for by the Charter. It was the United Nations decisions that transformed the US forces in Japanese territory into United Nations forces following the Korean Incident. By virtue of those decisions, the person who argued for security by the United Nations in order to secure the Peace Constitution, General MacArthur himself, was appointed the General of the United Nations Forces in Korea. The United Nations activities in Korea were far from impartial and peaceful, as is the case for every sanction. What makes it difficult for Japan to be indifferent to such a situation is the presence of the US forces as a result of the Japan-US Security Treaty. If Japan adheres to "neutrality" and "impartiality" on the part of the United Nations, she cannot assist in any forcible actions, even though United Nations decisions have given grounds for such actions. What the International Peace Cooperation Law intends is the clarification of the permitted scope of Japan's cooperation with the United Nations, restricted to that of an impartial nature peacekeeping. In fact, the scope is more restricted than that stipulated in the Law, by "freezing" cooperation with the main peace-keeping activities in the Law for the time being.

Aside from circumstances particular to any specific member state, the decisions of the Security Council are impartially binding on all members. ${ }^{31}$ As was shown in the aerial incident in Lockerbie in 1988, the decisions of the Security Council prevail even over the deliberations of the International Court of Justice. In this situation, it seems that Japan relies on the specific way she made peace with the Allied nations, involving continued stationing of US forces under the Peace Constitution, for the need to cooperate with United Nations' peace-keeping activities.

Under article 107 of the United Nations Charter, a so-called "enemy clause", matters regarding conclusion of peace after the Second World War were out of the jurisdiction of the organisation. On the other hand, in Japan's view the United Nations must be an organisation founded on good faith and impartiality, beyond the wartime "alliance". The fact is that the United Nations is not an impartial organisation especially as regards the constitution of the Security Council, the powers of its permanent members (including "selfjudgment"), lack of judicial review on its activities, and the non-removal of the "enemy clause" after accession of such states.

31 Charter article 25. 
Adding to the Charter article 53, another "enemy clause", led to the provision in article 51 for the "right of individual or collective self-defence". The security system based on confrontation of the two blocs after the Second World War developed on the basis of these exceptional clauses rather than the main part of the United Nations Charter. In 1949, the North Atlantic Treaty Organisation (NATO) was established among Western European nations and USA, admitting Western Germany to membership. To complement this system, the Warsaw Treaty Organisation was created among the Eastern European nations and the Soviet Union. They based their actions on self-defence under article 51 of the Charter. The "enemy clauses" could be the basis for agreements on cooperation, such as bilateral agreements between Eastern European nations and the Soviet Union, or the Sino-Soviet alliance against the revival of Japan.

The Japan-US Security Treaty was motivated by opposition to Communist offensives in the Far East, just as NATO was by opposition to Communism in Western Europe. As security for Germany found a solution in integration into the NATO system, security for Japan did so in the Treaty. What is peculiar to Japan is that the solution is contrary to the expectation at the time of the acceptance of the Constitution, namely assurance of "security by the United Nations".

Prime Minister Shigeru Yoshida was against rearmament after peace, a view shared with some other nations such as the Phillipines and Australia. Indeed, the Soviet Union and People's Republic of China would have been provoked by Japanese rearmament. However, in practical terms, peace with bases maintained in Japanese territory would amount to continued occupation and limit free exercise of foreign policy. ${ }^{32}$ The situation cannot be resolved without improvement in the United Nations system, as well as replacing the temporary solution of the Japan-US Security Treaty with a proper security system for Japan. This may be the first important task faced in the coming century.

32 India's preliminary view on the US Memorandum on the Japanese Peace Treaty, above n 11, 1382. 
(1997) 27 VUWLR 